\title{
Mollusks of the genus Biomphalaria Preston, 1910 in Amazon Region: first report of Biomphalaria occidentalis Paraense, 1981 in Pará State, Brazil
}

\section{Moluscos do gênero Biomphalaria Preston, 1910 na Região Amazônica: primeiro relato de Biomphalaria occidentalis Paraense, 1981 no estado do Pará, Brasil}

\author{
Christiane de Oliveira Goveia ${ }^{1,2}$, Roberta Lima Caldeira³, Márcio Roberto Teixeira Nunes ${ }^{4}$ Martin Johannes Enk \\ 1 Instituto Evandro Chagas, Seção de Parasitologia, Laboratório de Parasitoses Intestinais, Esquistossomose e Malacologia, Ananindeua, Pará, Brasil \\ 2 Universidade do Estado do Pará, Programa de Pós-Graduação em Biologia Parasitária na Amazônia, Belém, Pará, Brasil \\ ${ }^{3}$ Fundação Oswaldo Cruz, Instituto René Rachou, Grupo de Pesquisa em Helmintologia e Malacologia Médica, Belo Horizonte, Minas Gerais, Brasil \\ ${ }^{4}$ Instituto Evandro Chagas, Centro de Inovações Tecnológicas, Ananindeva, Pará, Brasil
}

\begin{abstract}
INTRODUCTION: In Pará State, Northern Region of Brazil, there are reports of the occurrence of Biomphalaria glabrata, Biomphalaria straminea, Biomphalaria schrammi, and Biomphalaria kuhniana. OBJECTIVE: To report the first existence of Biomphalaria occidentalis in Pará State. MATERIALS AND METHODS: Five mollusks were collected, examined for the presence of Schistosoma mansoni cercariae, and morphological and molecular taxonomies were performed. RESULTS: No specimens parasitized by trematode larvae were detected. Biomphalaria occidentalis was identified, being the first record in Pará State. CONCLUSION: The result obtained contributed to improve the knowledge about the dispersion and diversity of the Biomphalaria mollusks in Amazon Region.
\end{abstract}

Keywords: Biomphalaria; Mollusks; Polymerase Chain Reaction; Restriction Fragment Length Polymorphism; Schistosomiasis; Taxonomy.

\section{RESUMO}

INTRODUÇÃO: No estado do Pará, Região Norte do Brasil, há relatos da existência de Biomphalaria glabrata, Biomphalaria straminea, Biomphalaria schrammi e Biomphalaria kuhniana. OBJETIVO: Relatar a primeira ocorrência de Biomphalaria occidentalis no Pará. MATERIAIS E MÉTODOS: Cinco moluscos foram coletados, examinados quanto à presença de cercárias de Schistosoma mansoni e as taxonomias morfológica e molecular foram realizadas. RESULTADOS: Nenhum espécime parasitado por larva de trematódeo foi detectado. Foi identificada a espécie Biomphalaria occidentalis, sendo o primeiro registro no Pará. CONCLUSÃO: O resultado obtido contribuiu para melhorar o conhecimento sobre a dispersão e a diversidade de moluscos Biomphalaria na Região Amazônica.

Palavras-chave: Biomphalaria; Moluscos; Reação em Cadeia da Polimerase; Polimorfismo de Fragmento de Restrição; Esquistossomose; Taxonomia. 


\section{INTRODUCTION}

The genus Biomphalaria Preston, 1910 includes mollusks that may transmit Schistosoma mansoni, the etiological agent of schistosomiasis in Brazil. Among the 11 species and one subspecies of Biomphalaria genus that occur in the country, three are regarded as intermediate hosts of S. mansoni: Biomphalaria glabrata (Say, 1818), Biomphalaria tenagophila (d'Orbigny, 1835), and Biomphalaria straminea (Dunker, 1848). In Pará State, the species B. glabrata, B. straminea, Biomphalaria schrammi (Crosse, 1864), and Biomphalaria kuhniana (Clessin, 1883) have been already reported'.

The determination of species of the genus Biomphalaria is based on the comparison of morphological characters of shell, excretory system, and reproductive organs ${ }^{2}$; however, this can be difficult due to size of the specimens, inadequate fixation processes, and interspecific similarities ${ }^{3}$. These similarities even culminated in the grouping of some species of the genus Biomphalaria in two complexes: 1) B. straminea composed by B. straminea, Biomphalaria intermedia (Paraense \& Deslandes, 1962), and B. kuhniana; and 2) B. tenagophila containing B. tenagophila, Biomphalaria tenagophila guaibensis Paraense, 1984, and Biomphalaria occidentalis Paraense, $1981^{4,5,6,7}$. The species of $B$. tenagophila complex are indistinguishable from shell morphology and the majority of organs of the genital system. And only B. tenagophila is susceptible to infection with S. mansoni; therefore, the identification of these species is important for epidemiological studies of schistosomiasis ${ }^{7}$, and the knowledge of the geographical distribution of these species enable better resource distribution and adequate policies for the mollusk control $^{8}$. The molecular taxonomy has been used as an auxiliary tool to morphology when it is not enough for the species identification.

The present work aimed to report the first occurrence of B. occidentalis in Pará State, Northern Region of Brazil.

\section{MATERIALS AND METHODS}

Malacological surveys were carried out in May 2017 in the municipality of Afuá, Mesorregião Marajó, in Pará State, latitude $00^{\circ} 09^{\prime} 20.1^{\prime \prime S}$ and longitude 50²3'02.9"W.

Five specimens were collected using tongs and nets at sewage ditches from the urban perimeter containing garbage, by the collection period of $30 \mathrm{~min}$. No other species of mollusks or vegetation were observed in the sewage ditches during this time. The environment characteristics, where the specimens were collected, were favorable to the occurrence and dispersion of mollusks. A Garmin GPSMAP ${ }^{\circledR}$ 76CS Global Positioning System (GPS) receiver was used to record the geographic coordinates reading and all collection points were annotated and georeferenced.

The mollusks obtained were wrapped in gauze soaked in water, inserted in properly identified plastic bags, and stored in a rigid container in which they were transported to Laboratory of Intestinal Parasites, Schistosomiasis, and Malacology (LPIEM) of Parasitology Section (SAPAR) of Instituto Evandro Chagas (IEC). Five specimens were measured and individually packed in glass containers with $20 \mathrm{~mL}$ of dechlorinated water, exposed to artificial light (60 W incandescent lamp) for $30 \mathrm{~min}$, and then examined under a stereomicroscope to verify the presence of S. mansoni cercariae?. Subsequently, the mollusks were sacrificed, fixed ${ }^{10,11}$, and the foot of each specimen removed for DNA extraction by modified Wizard Genomic DNA Purification Kit (Promega).

The mollusks were identified morphologically by comparison of characters of the shell and the male and female reproductive organs according to Paraense ${ }^{2,4,5}$.

Molecular identification was performed by Laboratory of Helminthology and Medical Malacology, Instituto René Rachou/Fiocruz, using polymerase chain reaction and restriction fragment length polymorphism (PCR-RFLP) of the internal transcribed spacer (ITS) region of the RNA ribosomal genes, where the entire ITS was amplified with the primers ETTS2 (5' TAACAAGGTTTCCGTAGGTGAA 3') and ETTS1 (5' TGCTTAAGTTCAGCGGGT 3') anchored respectively in the conserved extremities of the 18S and $28 \mathrm{~S}$ ribosomal genes ${ }^{12}$. Subsequent was carried out cleavage of this fragment with the restriction enzymes Ddel and Alut, 13.

\section{RESULTS}

All specimens that were examined for the presence of S. mansoni cercariae were negative for the parasite and for other trematodes larvae.

All mollusks were morphologically identified as B. occidentalis (Figure 1).

The molecular results showing restriction profiles obtained by digestion of the ITS region of DNA ribosomal with Ddel were compared to the pattern of DNA profiles obtained from the Biomphalaria and Helisoma mollusks tissue from the Medical Malacology Collection (Fiocruz/CMM) (Figure 2).

To differentiate the species, the amplicon, previously obtained of approximately 1,200 base pairs, was submitted to a new RFLP using the restriction enzyme Alul', being possible to define the specie as B. occidentalis by molecular technique (Figure 3).

\section{DISCUSSION}

The geographic distribution of planorbid mollusks in Brazil is not well known due to the great territorial extension and the lack of human and economic resources; however, the number of studies aiming to better know the malacological fauna in some regions has increased ${ }^{14,15}$.

The present study is the first report of $B$. occidentalis in Pará State. In Brazil, this species was already found in Acre, Mato Grosso, Mato Grosso do Sul, Minas Gerais, Paraná, Rio Grande do Sul, Rondônia, Santa Catarina, São Paulo States, and there are reports of shells in Amazonas too ${ }^{1,4,16}$. 

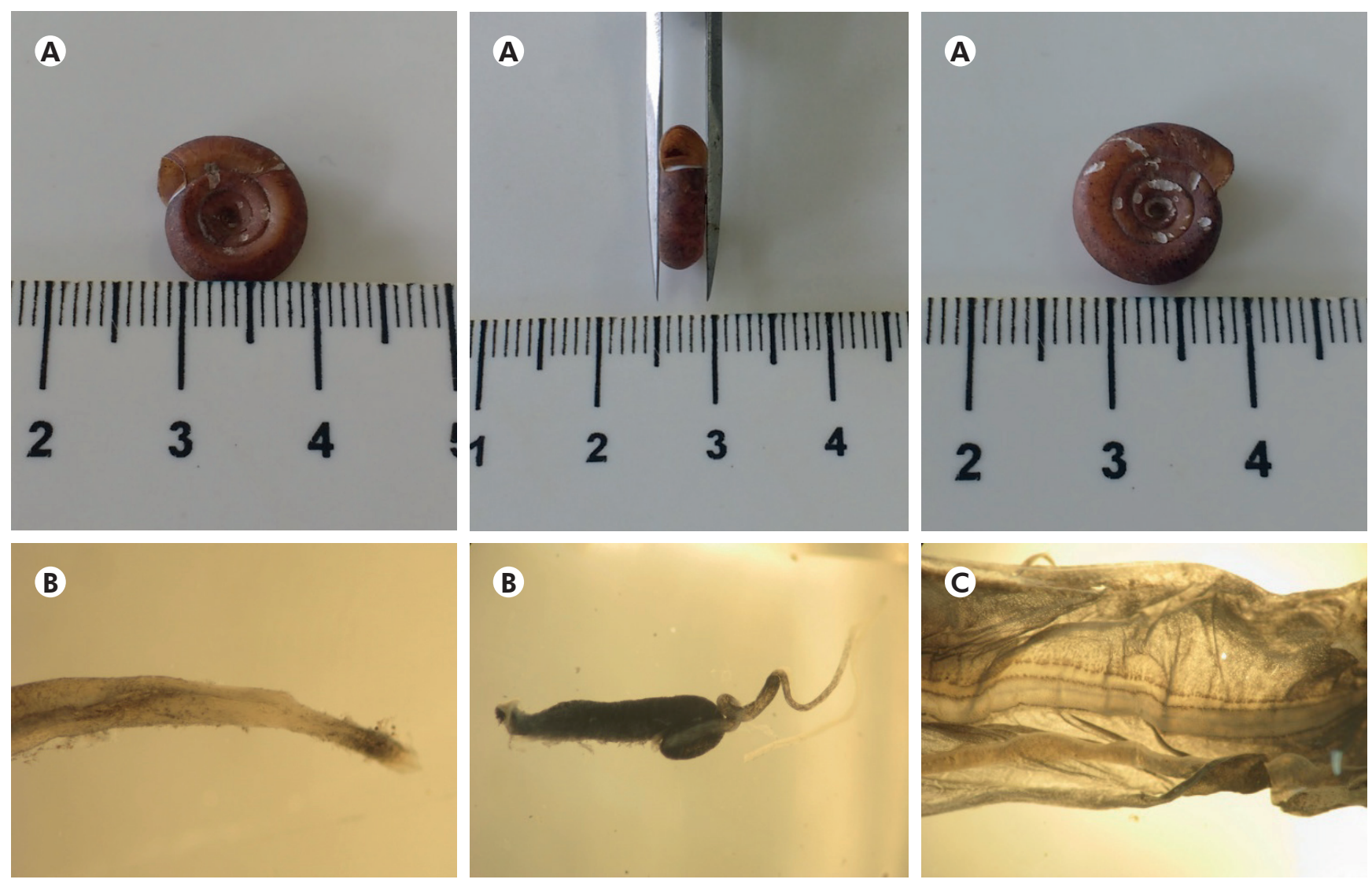

A: Shell; B: Reproductive system; C: Mantle with renal tube.

Figure 1 - Biomphalaria sp. from Afuá, Pará State, Brazil

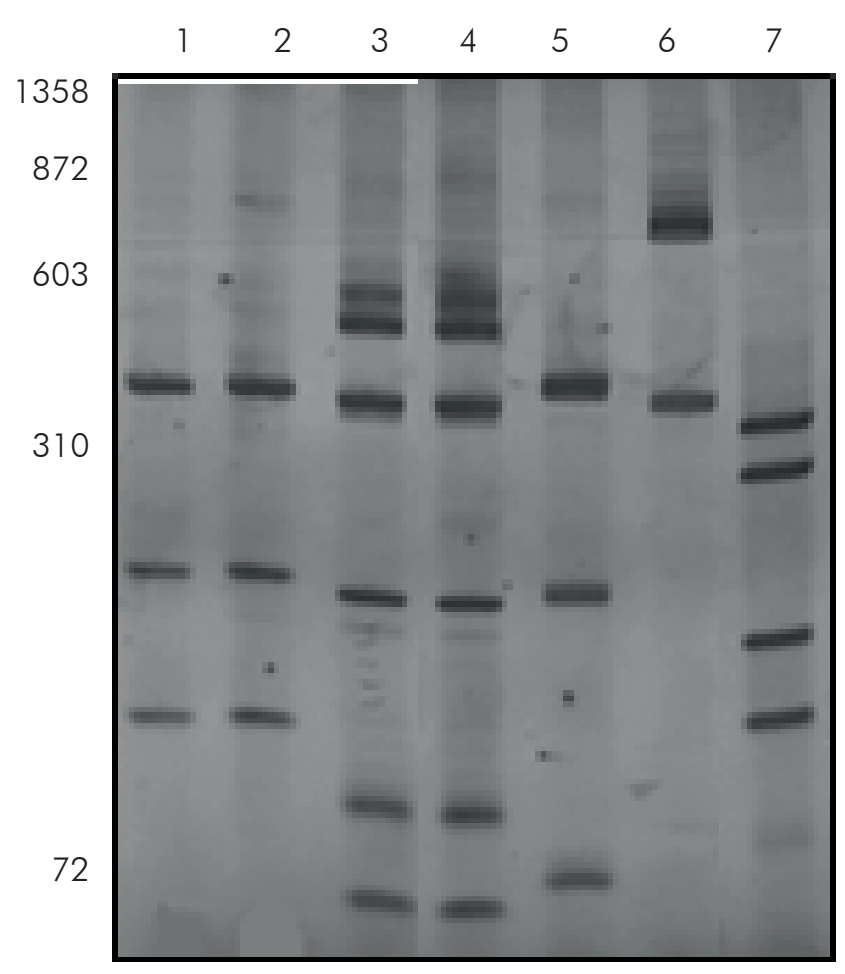

Lane 1: Biomphalaria sp. from Afuá, Pará State; Lane 2: B. occidentalis from Belo Horizonte, Minas Gerais State; Lanes 3 and 4: Helisoma sp. from Três Lagoas, Mato Grosso do Sul State; Lane 5: B. glabrata from Belo Horizonte, Minas Gerais State; Lane 6: B. tenagophila from Sabará, Minas Gerais State; Lane 7: Biomphalaria peregrina from Coromandel, Minas Gerais State. The numbers on the left of the gel are the value in base pairs (bp) of the molecular size markers Phi X 174/Haelll.

Figure 2 - Silver stained polyacrylamide gel (6\%) showing restriction profiles obtained by digestion of the ITS region of DNA ribosomal with Ddel

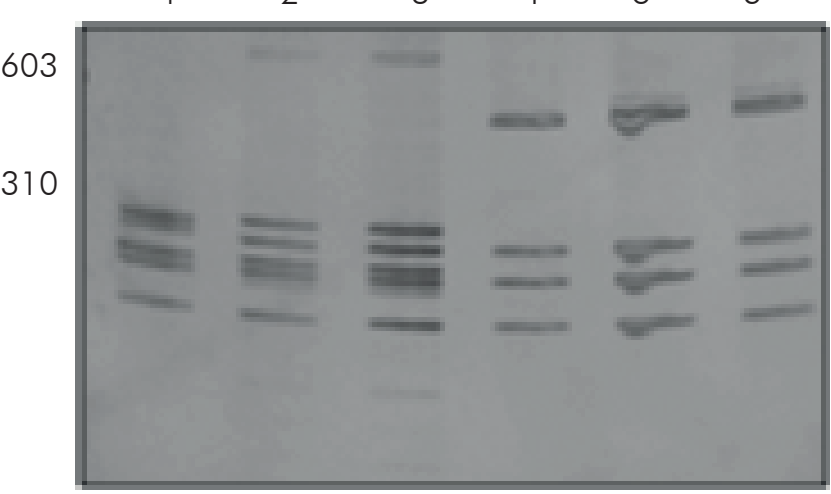

Lane 1: B. tenagophila from Sabará, Minas Gerais State; Lanes 2 and 3: B. t. guaibensis from Santa Vitória do Palmar, Rio Grande do Sul State; Lane 4: Biomphalaria sp. from Afuá, Pará State; Lanes 5 and 6: B. occidentalis from Belo Horizonte, Minas Gerais State. The numbers on the left of the gel are the value in base pairs (bp) of the molecular size markers Phi X 174/Haelll.

Figure 3 - Silver stained polyacrylamide gel (6\%) showing restriction profiles obtained by digestion of the ITS region of DNA ribosomal with Alul

The freshwater mollusks B. occidentalis, B. tenagophila, and B. t. guaibensis are morphologically similar, grouped in the complex B. tenagophila. Despite the morphological similarity among the species of the complex, only B. tenagophila is susceptible to $S$. mansoni, and several studies reinforced B. occidentalis as refractory species ${ }^{17,18,19}$; therefore the differentiation of these species is important to establish the vulnerable areas to the risk of occurrence of the schistosomiasis. 
Studies of the planorbid fauna in all areas of Brazil, mainly in less investigated regions, should be motivated by the objective of knowing the geographic distribution of Biomphalaria mollusks aiming the better resource distribution and adequate surveillance for its control.

\section{CONCLUSION}

This study presents the first record of $B$. occidentalis in the municipality of Afuá, Pará State.

In addition, the knowledge about the dispersion and diversity of the Biomphalaria mollusks in Brazilian Amazon was expanded.

\section{ACKNOWLEDGMENTS}

The authors thank to Carlos Faria, Carlos Júnior, Edilson Silva, Fernando Siqueira, and Fabíola Cardoso from LPIEM/SAPAR/IEC; and Amanda Araújo from
CMM of Instituto René Rachou Institute/Fiocruz, for their technical support.

\section{CONFLICT OF INTERESTS}

The authors declare that there is no conflict of interest.

\section{AUTHORS' CONTRIBUTION}

All authors contributed to the study idealization, analysis and interpretation of data and manuscript writing, approving the published final. They declare themselves responsible for content of the article, ensuring its accuracy and integrity.

\section{FINANCIAL SUPPORT}

Instituto Evandro Chagas, Secretaria de Vigilância em Saúde, Ministério da Saúde (IEC/SVS/MS).

\section{REFERENCES}

1 Carvalho OS, Passos LKJ, Mendonça CLGF, Cardoso CM, Caldeira RL. Moluscos brasileiros de importância médica. Série esquistossomose; 16. Belo Horizonte: Fiocruz, Centro de Pesquisas René Rachov; 2014. 92 p.

2 Paraense WL. Estado atual da sistemática dos planorbídeos brasileiros. Arq Mus Nac RJ. 1975 nov;55:105-28.

3 Caldeira RL, Teodoro TM, Jannotti-Passos LK, Lira-Moreira PM, Goveia CO, Carvalho OS. Characterization of South American snails of the genus Biomphalaria (Basommatophora: Planorbidae) and Schistosoma mansoni (Platyhelminthes: Trematoda) in molluscs by PCR-RFLP. Biomed Res Int. 2016;2016:1045391.

4 Paraense WL. Biomphalaria occidentalis sp.n. from South America (Mollusca Basommatophora Pulmonata). Mem Inst Oswaldo Cruz. 1981 Apr-Jun;76(2):199-211.

5 Paraense WL. Biomphalaria tenagophila guaibensis ssp. n. from southern Brazil and Uruguay (Pulmonata: Planorbidae). I. Morphology. Mem Inst Oswaldo Cruz. 1984 Oct-Dec;79(4):465-9.

6 Paraense WL. Biomphalaria kuhniana (Clessin, 1883), planorbid mollusc from South America. Mem Inst Oswaldo Cruz. 1988 Jan-Mar;83(1): 1 - 12.

7 Spatz L, Vidigal THDA, Caldeira RL, Dias Neto E, Cappa SMG, Carvalho OS. Study of Biomphalaria tenagophila tenagophila, B. t. guaibensis and $B$. occidentalis by polymerase chain reaction amplification and restriction enzyme digestion of the ribosomal RNA intergenic spacer regions. J Molluscan Stud. 1999 May;65(2):143-9.
8 Guimarães RJPS, Freitas CC, Dutra LV, Felgueiras CA, Moura ACM, Amaral RS, et al. Spatial distribution of Biomphalaria mollusks at São Francisco River Basin, Minas Gerais, Brazil, using geostatistical procedures. Acta Trop. 2009 Mar;109(3): 181-6.

9 Smithers SR, Terry RJ. The infection of laboratory hosts with cercariae of Schistosoma mansoni and the recovery of the adult worms. Parasitology. 1965 Nov; 55(4):695-700.

10 Deslandes N. Técnica de dissecação e exame de planorbídeos. Rev Serv Espec Saude Publica. $1951 ; 4: 371-82$.

11 Paraense WL. A natural population of Helisoma duryi in Brazil. Malacologia. 1976 Jan;15(2):369-76.

12 Kane RA, Rollinson D. Repetitive sequences in the ribosomal DNA internal transcribed spacer of Schistosoma haematobium, Schistosoma intercalatum and Schistosoma mattheei. Mol Biochem Parasitol. 1994 Jan;63(1):153-6.

13 Vidigal THDA, Caldeira RL, Simpson AJG, Carvalho OS. Further studies on the molecular systematics of Biomphalaria snails from Brazil. Mem Inst Oswaldo Cruz. 2000 Jan-Feb;95(1):57-66.

14 Nogueira RA, Lira MGS, Miranda GS, Rodrigues JGM, Gomes GCC, Silva-Souza N. Distribution of mollusks that transmit schistosomiasis in the endemic municipality of São Bento, Maranhão, Brazil. Rev Patol Trop. 2016;45(3):295-304.

15 Lopes TA, Nobushige SYL, Silva APS, Goveia CO, Enk MJ, Sampaio I, et al. Distribution and identification of the genus Biomphalaria Preston (1910): important insights into the epidemiology of schistosomiasis in the Amazon region. Rev Biol 2017;17(2):31-7. 
16 Paraense WL. A survey of planorbid mollusks in the Amazonian region of Brazil. Mem Inst Oswaldo Cruz. 1983 Jul-Sep;78(3):343-61.

17 Paraense WL, Corrêa LR. Unsusceptibility of Biomphalaria occidentalis to infection with a strain of Schistosoma mansoni. Mem Inst Oswaldo Cruz. 1982 Jan-Mar;77(1):55-8.

18 Coimbra Jr CEA, Engel LA. Suscetibilidade de Biomphalaria occidentalis do Acre e Mato Grosso à infecção pelo Schistosoma mansoni e sua implicação na epidemiologia da esquistossomose na Amazônia Ocidental, Brasil. Acta Amaz. 1982 dez;12(4):795-9.
19 Fernandez MA, Thiengo SC. Susceptibility of Biomphalaria amazonica and Biomphalaria occidentalis from Manso Dam, Mato Grosso, Brazil to infection with three strains of Schistosoma mansoni. Mem Inst Oswaldo Cruz. 2006 Oct;101 Suppl 1:235-7. 